\title{
PENDAMPINGAN PENGEMBANGAN MUTU PENYELENGGARAAN PESANTREN PADA LEMBAGA PENJAMINAN MUTU (LPM) PONDOK PESANTREN SALAFIYAH SYAFI'IYAH SUKOREJO
}

\author{
Dr. Maskuri, M.Pd.I \\ Universitas Ibrahimy Situbondo \\ masykuri.ismail@gmail.com
}

\begin{abstract}
Implementation of the boarding school from time to time to experience the dynamics of considerable interest to continue to be studied and explored. All schools in Indonesia continues to perform remediation efforts according to the times and the demands of society. It's time to make a breakthrough boarding innovative and creative in responding to the advancement of science and technology. As a user of the service organization of schools, the public has a "right" to provide corrections and contribute ideas for the development of quality schools. Because good and the quality of schools is closely related to public perception. In the context of understanding the dynamics of the development of schools to meet the needs of the service quality in order to produce good quality graduates, Boarding School in conjunction with the momentum Salafiyah Shafi'ites unification of universities in boarding schools, formed an organization that serves to accelerate the implementation of the quality of schools. The new institution called the Quality Assurance Agency Boarding School (Pesantren LPM) which is responsible to the Pesantren. Duties and functions are giving consideration to the development of quality caregivers for boarding. To know and understand how the LPM performance Pesantren, we perform community service through Pesantren LPM. Purpose and tujuannnya is providing assistance for the implementation of the vision and mission of the LPM, LPM know the planning and work, measures and follow-up activities, and how LPM involved in the process of quality development organization of schools. The new institution called the Quality Assurance Agency Boarding School (Pesantren LPM) which is responsible to the Pesantren. Duties and functions are giving consideration to the development of quality caregivers for boarding. To know and understand how the LPM performance Pesantren, we perform community service through Pesantren LPM. Purpose and tujuannnya is providing assistance for the implementation of the vision and mission of the LPM, LPM know the planning and work, measures and follow-up activities, and how LPM involved in the process of quality development organization of schools. The new institution called the Quality Assurance Agency Boarding School (Pesantren LPM) which is responsible to the Pesantren. Duties and functions are giving consideration to the development of quality caregivers for boarding. To know and understand bow the LPM performance Pesantren, we perform community service through Pesantren LPM. Purpose and tujuannnya is providing assistance.
\end{abstract}

Keywords: penyelenggaraan pesantren, pengembangan mutu, dan LPM Pesantren

\section{Latar Belakang}

Sejak berdiri sampai hari ini, pondok pesantren selalu melakukan upaya-upaya kemajuan sebagai wujud nyata mengikuti perkembangan zaman dan ilmu pengetahuan.

Langkah dan upaya kemajuan tersebut dilakukan dengan tetap mempertahankan identitas

Vol. 1 No. 1, April 2019 Dr. Maskuri, M.Pd.I| gurnal Pengabdian Masyarakat 
pesantren. Pesantren merupakan pusat peradaban dan pembentukan budaya yang berciri khas keislaman dan kemasyarakatan. Islam menjadi tersebar luas karena peran pesantren yang begitu besar. Tantangan dan peluang perkembangan zaman selalu mengiringi setiap langkah proses pengembangan pondok pesantren. hal yang paling banyak ditunggu oleh masyarakat luas adalah persoalan mutu, baik mutu layanan, mutu pendidikan, dan mutu yang sejalan dengan dinamika tuntutan masyarakat modern.

Sudah banyak pesantren yang telah melakukan modifikasi dan inovasi dalam hal memberikan layanan kepada masyarakat. Perdebatan dan dikotomi ilmu umum dan agama sudah tidak terdengar di kalangan pengelola pesantren. Untuk membuktikan hilangnya dikotomi itu, telah berdiri lembaga pendidikan berbasis ilmu sain dan teknologi, mulai dari pendidikan menengah sampai pendidikan tinggi. Proses inovasi atau pengembangan pesantren merupakan langkah menuju hasil yang maksimal sesuai dengan harapan masyarakat sebagai pengguna layanan penididikan pesantren. Berbenah dalam kelembagaan pesantren menjadi keniscayaan yang harus dilaksanakan dengan langkah nyata. Pendidikan yang tidak bermutu akan ditinggalkan oleh masyarakat. Demi mutu pendidikan, masyarakat dengan segala upayanya tidak memperhatikan berapa pun biaya yang harus dikeluarkan untuk mendapatkan hasil yang bermutu.

Adanya pergeseran keilmuan (lebih luas lagi dinamika keilmuan kiai dan guru-guru di pesantren) dan pelembagaan yang terjadi di pesantren tidak bisa dipisahkan dari peran kiai sebagai pemimpin sentral dalam pondok pesantren. Sentralisasi kekuasaan kiai memegang kendali yang cukup luas bagi pengembangan pesantren. " "Pergeseran kiai" yang terjadi dalam akhir-akhir ini juga dipengaruhi oleh pola interaksi kiai dengan dunia keilmuan dan pola modernisasi manajemen pendidikan maupun interaksi sosial lainnya. Karena itulah, maju mundurnya (bermutu atau tidak) pesantren sangat ditentukan oleh kiai sebagai pemegang sentral kekuasaan di pesantren. Untuk mengukur sejauhmana kemajuan itu, hasil atau produk menjadi parameternya, bermutu atau tidak! Namun, perspektif mutu sangat

${ }^{1}$ Nur Efendi, Manajemen Perubahan di Pondok Pesantren: Konstruksi Teoritik dan Praktik (Yogyakarta: Terass, 2014), 5. 
variatif dan dinamis di tengah-tengah masyarakat. Ada yang berasumsi atau berpendapat, bahwa mutu dimulai dari proses sampai menemukan hasil (keluaran). Di sisi lain, proses tidak menjadi tolok ukur, tetapi hasil dengan segala pelaksanaannya merupakan tolok ukur utama. Kajian mutu, baik proses maupun hasil tetap akan bersinergi, tidak berjalan sendirisendiri.

Dalam kontek pesantren sebagai basis ilmu keislaman, mutu bukanlah konsep baru, karena al-Qur'an sudah memberikan pesan kepada umatnya untuk melakukan pekerjaan dengan memperhatikan mutu, yaitu bekerja dengan kompetensi dan keahlian yang memadai:

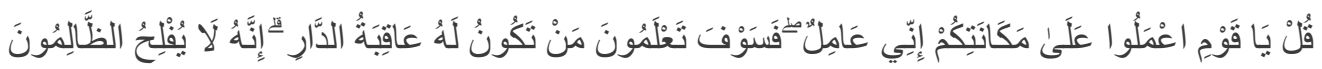

Artinya: Katakanlah: "Hai kaumku, berbuatlah sepenuh kemampuanmu, sesungguhnya akupun berbuat (pula). Kelak kamu akan mengetahui, siapakah (di antara kita) yang akan memperoleh hasil yang baik di dunia ini. Sesungguhnya orang-orang yang zalim itu tidak akan mendapatkan keberuntungan. ${ }^{2}$

Ayat di atas memang berkaitan dengan dialog Rasulullah dengan orang-orang kafir yang tidak mau menyembah Allah. Dengan nada mengingatkan Rasullah berkata: "wahai kaumku, berbuatlah sesuka hati kalian, sesungguhnya aku akan berbuat sesuai sesuai dengan ajaranku yang telah di syariatkan oleh Tuhanku kepadaku. Suatu saat kalian akan mengetahui, (ketika siksaan itu menimpa kalian) siapakah (diantara kita) yang akan memperoleh akibat yang baik? Sesungguhnya kalian tidak akan menggapai ridha Allah dan surgaNya jika berbuat melampaui batas dan melakukan tindakan aniaya dengan menyekutukan Allah, menyembah selain Dia."

Secara kontektual, ayat di atas juga dapat dijadikan sebagai inspirasi bagi kita semua, bahwa bekerja itu harus sesuai dengan keahlian, ilmu, dan ketrampilan untuk mencapai hasil maksimal ( sesuai ayat di atas adalah ridlo Allah). Mutu menjadi sarana sekaligus tujuan dalam melakukan upaya-upaya cerdas. Karena syarat pekerjaan yang

${ }^{2}$ Q.S. 6: 135.

Vol. 1 No. 1, April 2019

Dr. Maskuri, M.Pd.I|

Gurnal Pengabdian Masyarakat 
bermutu harus dilakukan dengan keahlian dan keseriusan yang disertai ketrampilan (كا نتكم) ). Betapa pentingnya mutu dalam segala aspeknya.

Mutu dalam percakapan sehari-hari sering dimaksudkan sebagai suatu yang absolut. Sebagai contoh mutu adalah bila kita merasakan makanan enak di sebuah restoran atau rumah makan. Kesan yang terucap adalah makanan ini sedap, pasti bermutu, dikerjakan oleh juru masak profesional. Bila kita melihat mobil mewah, rasanya ingin berucap mobil itu pasti bermutu karena yang menumpangi akan merasakan kenyamanan. Realita ucapan tersebut digunakan sebagai standar mutu yang selalu identik dengan mewah, cost yang tidak sedikit, dan tidak dapat diungguli. ${ }^{3}$ Dalam hal pendidikan, masyarakat akan mengatakan, lulusan lembaga pendidikan dikatakan bermutu jika peserta didik melanjutkan studi di perguruan tinggi terkenal. Jika bekerja dalam sebuah perusahaan, bukan pada level pekerja kasar. Dan, apalagi jika mampu membuka lapangan kerja dengan karyawan di atas standar ketenaga kerjaan.

Sangat bertalian dengan out put dan out come, bahwa mutu memang menjadi harapan semua orang, tanpa terkecuali. Lembaga pendidikan Islam, sebagian masih dianggap belum mampu mengisi ruang mutu secara keseluruhan. Sebenarnya tidak salah jika lulusan pondok pesantren, yang dalam undang-undang disebut sebagai salah satu bentuk pendidikan keagamaan, tidak mengisi ruang kerja professional. Pendidikan keagamaan diselenggarakan dalam rangka melahirkan manusia yang ahli ilmu-ilmu keagamaan Islam. Namun, seiring perkembangan ilmu pengetahuan dan teknologi yang begitu cepat, pendidikan Islam sudah tidak lagi memfokuskan pada ilmu-ilmu keagamaan an sich. Jika kita pernah mendengar persaingan ekonomi yang besar akan mengalahkan yang kecil, hari ini berbeda, yang cepat akan mengalahkan yang lambat.

Untuk memenuhi kebutuhan ruang mutu yang didukung profesionalitas, lembaga pendidikan Islam harus memacu secara cepat dan tepat. Bukan persoalan harapan saja, tetapi memang kenyataan empiris mutu pendidikan Islam. Dibutuhkan mental perubahan yang kuat dan siap, serta mampu mengelola kebijakan mutu yang dibentuk oleh Negara. Hal

3 Abuddin Nata, Kapita Selekta Pendidikan Islam: Isu-isu Kontemporer tentang Pendidikan Islam (Jakarta: Rajagrafindo Persada, 2016), 47. 
penting yang harus diperhatikan juga adalah bagaimana manajemen perubahan melakukan peningkatan mutu pendidikan Islam.

Pondok pesantren Salafiyah Syafi'iyah yang sudah berumur lebih dari 100 tahun ( 1 abad lebih, tepatnya pada tahun 2014 sebagai puncak peringatannya ) dengan segala potensi yang ada, telah membuktikan keniscayaan untuk selalu berkembang sesuaui kebutuhan zaman. Pada awal tahun 2018, pesantren ini mengambil langkah strategis dan taktis, yaitu melakukan alih status Peguruan Tinggi; Institut Agama Islam (IAII) menjadi Universitas Ibrahimy (UNIB). Momentum "berdirinya kembali” perguruan tinggi menjadi pintu masuk untuk melakukan langkah yang lebih teknis dan operasional untuk mengakselerasi kemajuan agar ke depan pesantren bisa bermusabaqoh secara baik dengan perguruan tinggi lainnya. Untuk memenuhi kebutuhan teknis operasional itu, dibentuklah lembaga yang berkonsentrasi dalam pengembangan mutu, yaitu Lembaga Penjaminan Mutu Pondok Pesantren (LPM P2). Lembaga baru inilah yang selanjutnya menterjemahkan "kemaunya" Pengasuh (pemegang pemimpin tertinggi di pesantre) dalam proses dan pelaksanaan mutu pendidikan dan mutu pesantren.

\section{Permasalahan}

Mewujudkan cita-cita mulia, yakni menjadikan mutu penyelenggaraan pendidikan (dengan segala kebutuhan) di pesantren bukanlah pekerjaan mudah, perlu memahami isuisu strategis dan problematika yang sudah dan sedang berjalan. Karena itu, perlu dipahami dan diketahui apa saja yang menjadi permasalahan. Dalam pengabdian masyarakat ini, saya bersama tim yang tergabung dalam penjaminan mutu pesantren mengidentifikasi beberapa permasalahan, yaitu :

1. Tuntutan kebutuhan masyarakat yang terus berkembang sesuai dinamika kemajuan zaman.

2. Perkembangan ilmu pengetahuan dan teknologi serta informasi yang terus berjalan begitu cepat, sebagaimana tergambarkan dalam revolusi industri 4.0.

3. Bertambahnya jumlah santri dan kebutuhan sarana prasarana yang terus bertambah setiap tahun. 
4. Perubahan status perguruan tinggi dengan bertambahnya jumlah program studi, baik berbasis keagamaan maupun riset dan teknologi.

5. Masih belum ada dokumentasi yang tertata secara rapi sebagai pusat informasi dan pengambilan kebijakan yang materinya berupa nilai-nilai filosofi dan sosiologis, sebagaimana telah dibangun para pendahulunya.

6. Perlu ada penyempurnaan tata kelola kelembagaan pesantren, terutama menyangkut kebutuha penyempurnaan pedoman penyelenggaraan pesantren, tata kelola keuangan, dan tata naskah di lingkungan pesantren.

7. Internalisasi nilai-nilai kepesantrenan dan pemahaman keagamaan Islam Ahlus Sunnah wal Jama'ah sebagai fondasi dalam penyelenggaraan pesantren, pola interaksi kebangsaan, kenegaraan, dan kemasyarakatan, harus menjadi kesepahaman bersama bagi pengelola dan pemangku pesantren.

\section{Tujuan}

Sebagai salah satu tim penjaminan mutu pesantren, yang sekaligus pendamping dalam proses akselerasi pencapaian mutu penyelenggaraan pesantren, dan perwujudan pengabdian kepada masyarakat, maka penjaminan mutu pesantren memiliki tujuan sebagai berikut:

1. Terwujudnya budaya mutu di lingkungan pondok pesantren

2. Menyusun beberapa dokuman pedoman penyelenggaraan pesantren, seperti pedoman kepengurusan, pedoman tata kelola keuangan, pedoman tata naskah, dan pedoman pelaksanaan unit-unit organisasi yang ada di pesantren.

3. Memberikan pemahaman yang sama bagi umana' dan pengelola unit-unit organisasi pelaksana kebijakan pesantren agar bisa berjalan dengan tertib dan bertanggungjawab.

4. Mendorong terwujudnya tujuan-tujuan kelembagaan di lingkungan pesantren agar sejalan dengan visi dan misi pondok pesantren.

5. Mempercepat proses penyusunan rencana strategis dan pengembangan pesantren.

\section{Signifikansi}


Lembaga penjaminan mutu pondok pesanten yang baru berdiri ini menjadi penting keberadaannya bagi proses keberlangsungan penyelenggaraan pendidikan dan pengabdian pesantren bagi pemenuhan layanan masyarakat dan tuntutan kebutuhan zaman. Pendampingan kegiatan penjaminan mutu ini memiliki signifikansi sebagai berikut:

1. Memberikan kontribusi bagi penyelenggaraan pendidikan pesantren agar bisa menyesuaikan dengan kebutuhan zaman.

2. Memberikan masukan dan pertimbangan dalam proses kemajuan kelangsungan pendidikan dan layanan umat.

3. Menyatukan persepsi bagi pelaksana unit-unit organisasi dalam menjalankan tugas kepesantrenan.

4. Ikut terlibat dalam proses pembentukan lingkungan budaya mutu bagi semua pelaksana kegiatan yang ada dalam unit-unit organisasi di pesantren.

5. Memberikan pendampingan bagi terlaksananya visi, misi, dan usaha-usaha pesantren dalam pengembangan seluruh unit-unit pesantren

\section{Gambaran Umum Lokasi Pendampingan}

Usia Pondok Pesantren Salafiyah Syafi'iyah, Sukorejo, Situbondo (selanjutnya ditulis Pesantren Sukorejo) sudah mencapai 103 tahun, usia yang bukan sekedar cukup, tapi matang, melampaui batas idealisme. Berdiri pada tahun 1914 M, sebagaimana catatan dalam beberapa dokumen sejarah berdirinya pondok pesantren Sukorejo, secara spesifik diceritakan dalam Buku Biografi KHR. As'ad Syamsul Arifin yang ditulis oleh Chairul Anam. Bukut tersebut menjadi buku wajb bagi setiap orang yang belajar, atau berkunjung ke pesantren Sukorejo. Setiap santri baru, orang yang baru mondok hampir dipastikan mendapatkan buku biografi tersebut. Selain santri baru, hampir setiap kunjungan tamu (terutama tamu resmi, yaitu tamu yang berkunjung dengan terlebih dahulu memberi tahukan ke pesantren secara resmi) diberi "kado" buku biografi. Pemberian buku, kepada santri baru atau tamu (sebagai contoh dari sekian orang yang mendapatkan buku) dimaksudkan agar mereka yang berkunjung dan menetap di pesantren Sukorejo emperoleh informasi yang cukup untuk mengetahui sejarah berdirinya pesantren Sukorejo. 
Pesantren Sukorejo yang sudah masuk kategori tua tersebut tentunya akan terus dijaga oleh penerusnya agar tetap lestari dan menjadi amal jariyah yang mengalir tanpa batas tepi dan akhir. Para penerus, mulai dari Kiai As'ad (wafat tahun 1991) dan KHR. Ach, Fawaid ( wafat tahun 2012) berusaha sekuat tenaga, dengan ijtihad mandiri dan kolektif untuk membangun dan mengembangkan Pesantren Sukorejo sebagai wadah penempaan ilmu keagamaan Islam. Kiai Fawaid dalam berbagai kesempatan sering menyampaikan, bahwa dirinya hanya meneruskan, bukan pemilik pondok pesantren. Pemilik sesungguhnya pesantren ini adalah Kiai Sepuh (KHR. Syamsul Arifin, maksudnya) yang membabad, "bertapa" dengan lelaku supra natural transendental. Siapa pun yang memimpin Pesantren Sukorejo harus mampu menjaga warisan para pendahulunya. Hal-hal yang berkaitan dengan kemajuan dan perubahan Pesantren harus mengacu pada tradisi yang sudah dibangun oleh Kiai Sepuh. Perubahan merupakan sunatullah yang tidak bisa dielakkan, karena menolak perubahan berarti melawan ketentuan Allah. Pesantren Sukorejo harus berkembang sesuai dengan dinamika dan kebutuhan masyarakat yang selalu bersamaan dengan berjalannya zaman. Dan, perubahan tidak lain adalah untuk menuju mutu pesantren. Sebuah idealisme yang menjadi dambaan setiap penyelengara pendidikan (Islam).

Selepas kepemimpinan KHR. Ach, Fawaid As'ad, Pesantren Sukorejo beralih kepada KHR. Ahmad Azaim Ibrahimy sebagai pengasuh keempat. Jumlah santri yang belajar di Pesantren Sukorejo, dari tahun ke tahun, melalui rekrutmen santri baru, dari pendidikan dasar sampai pendidikan tinggi terus bertambah. Jumlah santri yang terus meningkat secara kuantitatif menjadi pemikiran para pengurus dan pengelola lembaga pendidikan. Pemikiran yang selalu menjadi perhatian serius adalah bagaimana santri menjadi generasi muslim kohiru ummah, generasi yang selalu tampil dengan performa muslim sejati, apa paun peran dan kedudukan santri, harus benar-benar menjadi teladan bagi umat lainnya. Pembentukan santri yang berkualitas tentu membutuhkan perangkat yang memadai. Kiai Azaim (biasa dipanggil), memegang peran yang sangat strategis, karena Pesantren Sukorejo, siapa pun pengasuhnya adalah pemegang kekuasaan sentral (terpusat dan tertinggi). Untuk mewujudkan cita-cita dan visi mulia tersebut, Kiai Azaim dengan segala kemampuan dan bekal pengalaman yang dimilikinya melakukan lompatan perubahan dan kemajuan yang

\section{Vol. 1 No. 1, April 2019}


cukup penting. Salah satu lompatan itu adalah mengembalikan status perguruan tinggi, sebagai amanah dari pengasuh sebelumnya (Kiai Fawaid). Peralihan status perguruan tinggi ini menjadi perhatian serius oleh pengasuh Pesantren Sukorejo. Karena itulah, Lembaga Penjaminan Mutu Pondok Pesantren (disingkat LPM) sebagai lembaga baru mendapat tanggung jawab besar dan berat. Amanat pertama yang harus dijalankan oleh LPM adalah melakukan pendampingan kepada perguruan tinggi.

Keberadaan LPM sebagai lembaga baru tentu menjadi pertanyaan para umana' atau pengurus Pesantren Sukorejo yang lain. Untuk memberikan pemahaman yang sama dan visi bersama, LPM harus melakukan sosialisasi dan koordinasi dalam beberapa kebijakan baru yang harus diselesaikan dalam jangka pendek. Kebijakan baru tersebut adalah ikut serta dan terlibat dalam proses penyempurnaan pedoman pesantren, sebuah pedoman yang berisi berbagai peraturan untuk menjadi pedoman bagi pengurus dan umana' Pesantren Sukorejo. Konten pedoman pesantren itu antara lain: peraturan tentang pelaksanaan tugas dan tanggung jawab pengurus, mekanisme pelaporan kinerja, tata kelola dan mekanisme rekrutmen pengurus, dan pengaturan mengenai pemberian barokah, yaitu pemberian "gaji" bulanan bagi setiap orang yang mengabdikan dirinya ke pesantren.

Selain pedoman pesantren, LPM juga diberi tanggung jawab untuk menyusun dokumen perencanaan strategis (renstra) Pesantren Sukorejo. Renstra ini diharapkan menjadi pedoman pengelolaan dan penyelenggaraan pesantren dalam proses pengembangan dan kemajuan ke depan. Agar nilai-nilai kepesantrenan yang sudah dibangun pendiri pertama dan pemimpin sebelumnya, perlu digali berbagai sumber informasi dan data mengenai filosofi pesantren. Mana nilai-nilai yang harus dipertahankan, sebagai harga mati, dan wilayah mana saja yang dapat dikembangkan, sebagai langkah maju dalam mengikuti perkembangan dan kebutuhan masyarakat modern? Para pengasuh pendahulu tidak pernah alergi dengan perubahan dan pengembangan, karena dua hal tersebut memang sudah menjadi perintah suci dari Allah. Yang tidak boleh berubah adalah akidah Islam Ahlus Sunnah wal Jama'ah, pemisahan santri putra dan putri dalam proses pembelajaran, memakai busana muslim berkarakter salafiyah, sholat berjamaah, membaca aurod (dzikir harian yang

\section{Vol. 1 No. 1, April 2019}


tertuang dalam al-adzkar al-yaumiyah, dan nilai-nilai atau tradisi ubudiyah yang sudah berakar dan berkembang dalam proses penyelenggaraan pesantren.

\section{Kondisi saat ini Masyarakat Dampingan}

Dalam kurun waktu yang cukup singkat, sejak tahun 2012, di bawah kepemimpinan KHR. Ahmad Azaim Ibrahimy, sudah banyak yang dilakukan oleh Pesantren Sukorejo dalam proses pembaharuan (inovasi). Sebagaimana dijelaskan dalam gambaran umum di atas, bahwa pesantren Sukorejo melakukan upaya pembaharuan, adalah sebagai wujud nyata tanggung jawab pemenuhan mutu pendidikan, tuntutan zaman, dan kebutuhan masyarakat. Namun kondisi saat ini, Pesantren Sukorejo dengan jumlah santri yang semakin bertambah menuntut pengelolaan dengan pola manajemen modern berbasis ma'hady. Manajemen tersebut dimaksudkan untuk melakukan langkah nyata dalam bentuk pelembagaan dan internalisasi nilai-nilai yang sudah berkembang cukup lama dan mengakar. Karena, pengelolaan dan penyelenggaraan pesantren yang hanya fokus pada perubahan dan kemajuan dengan pola manajemen modern tanpa memperhatikan nilai-nilai pesantren yang ada, akibatnya akan kehilangan identitas. Hal-hal yang sudah mentradisi menjadi simbol interaksi hamba kepada Allah dan pergaulan sosial kemasyarakatan sebagai bagian mahluk sosial. Fungsi pesantren, selain layanan pendidikan, juga layanan pengabdian kepada masyarakat.

Pemenuhan saranan prasarana berupa bangunan gedung untuk penyelenggaraan pendidikan, asrama santri, dan bentuk fisik lainnya bukan dalam hanya sekedar pemenuhan fisik belaka. Semua yang dilakukan, baik fisik maupun non fisik memiliki tujuan sebagai perangkat mencapai mutu pendidikan.

\section{Kondisi yang Diharapkan}

Memperhatikan kondisi dan keberadaan Pesantren Sukorejo dengan LPM sebagai unit organisasi baru yang bergerak dalam pengembangan mutu pesantren, ada harapan ke depan untuk membangun organisasi besar ini menjadi organisasi yang maju. Pengelolaan organisasi yang maju harus didukung oleh Sumber Daya Manusia (SDM) dan sumber potensi lain yang berjalan secara sinergis. Satu sama lain, dalam satu wadah organisasi Pesantren Sukorejo harus terintegrasi dalam sistem pengelolaan dan penyelenggaraan

\section{Vol. 1 No. 1, April 2019}


pesantren, sehingga semua unit-unit organisasi sebagai pelaksana visi dan misi mulia pesantren dapat berjalan dalam satu koridor yang menyatu. Semangat nilai-nilai ilahiyah yang telah tertanam dalam pribadi para pengurus adalah modal penting dalam menjalan satu sistem kepesantrenan. Organisasi yang kuat bukan hanya mengandalkan struktur yang rapi dan tertib, tetapi jauh dari itu semua yang lebih penting adalah para pelaksana kebijakan pesantren.

Harapan besar yang harus menjadi niatan kolektif para pengurus dan pelaksana organisasi dalam mencapai mutu pesantren harus terinternalisasi. Mutu sebagai cita-cita bersama memang membutuhkan sinerji dan kekompakan semua unsur-unsur penyelenggara dan pengelola. Untuk mencapai semua kepentingan mutu pesantren, budaya mutu menempati rangking yang mendasar dalam penyelenggaraan pesantren. Apa yang sudah ditetapkan dalam pedoman organisasi dan seluruh perangkat organisasi hanyalah sarana untuk mendukung budaya kerja yang berorientasi mutu. Budaya mutu itu antara lain kedisiplinan, taat asas penyelenggaraan pesantren, akuntabilitas, integritas, kualitas/kapabilitas, bekerja tanpa ada unsur paksaan, pergaulan dengan membudayakan kinerja yang rapi, dan lain sebagainya.

Persoalan mutu menjadi tolok ukur kemajuan pesantren dalam menatap masa depan yang semakin ketat dalam proses persaingan. Kebutuhan dan tuntutan kerja maksimal, dengan dilandasi nilai-nilai keagamaan Islam, bukan lagi slogan dan motto persembahan, tetapi terpatri dalam indvidu setiap pengelola unit-unit organisasi. Untuk mengukur mutu dengan basis kemajuan harus diberi standarisasi yang implementatitf. Pesantren dalam hubungannya dengan penyelenggaraan pendidikan yang telah diatur dalam satu sistem pendidikan nasional sebenarnya sudah ada standarisasinya. Agar identitas pesantren sebagai subkultur tidak larut dalam "pengaturan Negara", standarisasi atau perangkat untuk mengukur keberhasilan harus jelas. Ada aliran relativisme dalam memandang sebuah kamajuan, yaitu anggapan maju antara satu kelompok dengan kelompok lain, individu satu dengan individu lainnya tidak sama, tergantung cara pandang dan alat ukur. Ada yang menganggap maju dalam bidang teknologi, tapi mereka tidak maju dalam penanaman nilai-nilai agama, begitu pun sebaliknya, maju dalam penanaman 
keagamaan tapi tidak dibarengi dengan bidang lain akan mengalami ketimpangan. Apa pun anggapan kemajuan tersebut, dalam proses pencapaian mutu, Pesantren Sukorejo mempunyai standar sendiri, dengan tetap memperhatikan kebutuhan dan tuntutan masyarakat.

\section{Strategi Pelaksanaan}

Dalam pelaksanaan pengabdian masyarakat melalui LPM Pesantren, saya bersama tim yang memang bergabung dalam LPM menyusun rencana pelaksanaan dengan tahapan sebagai berikut:

1. Perencanaan

Dalam melaksanakan pendampingan terhadap kegiatan pengabdian kepada masyarakat di LPM, sebagai lembaga yang bertanggungjawab terhadap mutu pesantren, perlu merumuskan rencana yang akan dilakukan ke depan. Proses merencanakan ini dilakukan bersama tim dan pengurus LPM. Konsolidasi internal untuk menyamakan persepsi sesama pengurus LPM, menyususn rencana kerja dan anggaran, menyusun mekanisme kerja dan tata kelola organisasi, dan sosialisasi kepada seluruh unit-unit organisasi atas keberadaan LPM. Kegiatan perencanaan pendampingan ini dilaksanakan pada bulan September tahun 2018 sampai Januari 2019.

2. Pelaksanaan

Kegiatan pendampingan ini dilaksanakan selama masa September sampai Januari dengan tahapan sebagaimana rencana kerja. Sebagai orang yang terlibat dalam kepengurusan LPM, saya bersama dengan team work terlibat secara langsung untuk ikut menyusun seluruh perencanaan dan sekaligus melaksanakan kegiatan yang sudah menjadi rencana kerja. Selain tahapan sebagaimana disebutkan di atas, tim dan LPM juga ikut secara aktif dalam proses pembahasan beberapa dokumen penting Pesantren Sukorejo.

Kegiatan pendampingan bersama tim LPM dimaksudkan untuk mengawali konsolidasi bagi kelembagaan LPM. Ke depan LPM harus menjadi institusi yang benar-benar memberikan konstibusi bagi pengembangan pesantren. konsep, perencanaan, aksi, dan evaluasi adalah tahapan kegiatan yang seharusnya dilaksanakan. Jadi, pelaksanaan 
pendampingan bersama LPM dilaksanakan berdasarkan perencanaan, diluar perencanaan LPM bekerja sesuai dengan dinamika perkembangan Pesantren Sukorejo. Dinamika itu tidak keluar dari apa yang memang seharusnya dilakukan oleh LPM. Masih berkaitan dengan kosntribusi LPM, pembahasan Rancangan Undang-Undang tentang Pesantren dan Pendidikan Keagamaaan yang telah resmi menjadi usul DPR RI dan terus menggelinding bak bola salju di kalangan penyelenggara pesantren, menjadi perhatian serius Pesantren Sukorejo. Untuk memperdalam RUU tersebut, LPM menjadi penanggung jawab kegiatan yang di dalamnya termasuk melakukan inventarisasi masalah dan merumuskannya menjadi bahan materi yang dibahas bersama dengan para kiai dan pengasuh pesantren se Nusantara.

3. Evaluasi

Setiap melaksanakan kegiatan, LPM (yang di dalamnya saya menjadi salah satu pengurus) selalu mengadakan evaluasi. Bentuk evaluasinya dilakukan melalui dua jalur, yaitu jalus formal dan informal. Pada jalur formal, LPM sesusai mekanisme dan tata kerja yang sudah diatur, mengadakan rapat rutin yang diselenggarakan setiap satu minggu sekali, yaitu pada setiap hari Sabtu (malam Ahad) bertempat di kantor LPM. Dalam forum rapat tersebut, LPM mengevaluasi seluruh kegiatan yang sudah dilaksanakan, baik kegiatan internal murni maupun kegiatan bersama dengan pengasuh serta pengurus pesantren. sedang pada evalusi jalur informal dilakukan dengan cara kontak person sesame pengurus LPM. Ada group WA yang memang disediakan sebagai forum komunikasi informal.

4. Tindak Lanjut

Setelah diadakan evaluasi, LPM merencanakan tindak lanjut sesuai catatan dan pertimbangan yang dihasilkan melalui evaluasi. Tindak lanjut program diutamakan bagi pelaksanaan kegiatan yang sudah direncanakan sebelumnya. Sementara masukan dan pertimbangan yang dihasilkan dari evalusi, dalam pelaksanaan tindak lanjut dilakukan melalui koordinasi dengan unit-unit organisasi. Seperti yang sudah menjadi amanat LPM, saat pertama dibentuk, yakni keterlibatan dalam proses penyempurnaan perangkat 
perguruan tinggi Universitas Ibrahimy (Unib). Perangkat tersebut seperti penyusunan Statuta Unib yang mejadi kewajiban bagi setiap perguruan tinggi swasta.

Pendampinangan LPM terhadap Unib bukan hanya pada rancangan statuta, ada banyak rencana tindak lanjut yang harus dilaksanakan oleh LPM bagi kelangsungan penyelenggaraan pendidikan tinggi dan pengelolaan perguruan tinggi. Ini bukan pekerjaan mudah, karena Unib sebagai perguruan tinggi swasta yang "memiliki dua kepala”, yaitu kepala Kementerian Agama dan Kementerian Riset Teknologi dan Pendidikan Tinggi Republik Indonesia, harus mampu mengkoordinasikan seluruh pelaksanaan kegiatannya dengan mengacu pada regulasi yang dibentuk oleh pemerintah, terutama dua kementerian tersebut.

\section{Kajian Teori}

Kajian mutu sering dikaitkan dengan sebuah hasil dari upaya yang dilakukan seseorang atau kelompok. Masyarakat beranggapan bahwa pendidikan yang bermutu adalah pendidikan yang mampu menghasilkan lulusan atau alumninya menjadi manusia sukses. Sebaliknya, lembaga pendidikan dikatakan tidak bermutu manakala lulusannya belum menunjukkan kinerja yang baik dan produktif. Dalam konteks mutu lulusan lembaga pendidikan, parameter mutu tentu tidak hanya ditentukan oleh satu indikator. Sebagian masyarakat beranggapan, sekolah atau lembaga pendidikan dikatakan bermutu manakala lulusannya banyak yang melanjutkan ke perguruan tinggi pavorit. Namun, ada juga kelompok masyarakat yang mengatakan, pendidikan bermutu adalah pendidikan yang menghasilkan lulusan sebagai manusia yang baik, menjadi tauladan bagi kehidupan masyarakat dan selalu memfasilitasi penyelesaian problem kemasyarakatan. Parameter mutu atau kemajuan memang relativ, tergantung bidang apa yang menjadi ukuran kemajuan. Apa yang dikatakan seseorang maju (bermutu) belum tentu mendapat anggapan maju bagi orang lain. Mesti ada parameternya, bidang apa dan untuk siapa kemajuan itu dicapai? Ini yang dimaksud dengan tingkatan kemajuan yang dibatasi oleh relativisme. Namun, untuk mengukur sebuah komunitas itu maju, harus ada kesepakatan dalam tubuh organisasi itu. ${ }^{4}$

${ }^{4}$ Piotr Sztompka, Sosiologi Perubahan Sosial (Jakarta: Prenada, 2011), 28

Vol. 1 No. 1, April 2019 Dr. Maskuri, M.Pd.I| gurnal Pengabdian Masyarakat 
Asumsi atau persepsi publik terhadap mutu pendidikan yang sangat beragam tersebut tidak berdiri sendiri. Ada banyak faktor yang mendasari asumsi relativisme tersebut, perkembangan media informasi yang begitu deras dan cepat, kemajuan ilmu pengetahuan dan teknologi, interaksi lintas sosial, dan perkembangan media sosial yang begitu deras serta cepat. Mutu telah menjadi trend dan alternatif dalam memilih pendidikan, tidak penting biaya mahal jika hasilnya menambah kepuasan dan kebaikan. Sebagai contoh, merebaknya toko-toko modern yang berjejer hampir di sepanjang jalan raya telah menjadi alternatif bagi masyarakat yang hendak memenuhi kebutuhan sesaat untuk memenuhi kepuasan. Padahal jika dibandingkan dengan harga di toko tradisional yang dikelola masyarakat umum, selisihnya cukup lumayan tinggi. Namun mutu pelayanan dan kenyamanan konsumen terpenuhi saat baru memasuki toko modern. Mutu telah berubah menjadi gaya hidup masyarakat sekarang, bukan hanya dunia pendidikan, tetapi persoalan tampilan gaya hidup sudah menjadi kebutuhan.

Mutu telah menjadi isu yang sangat penting bagi seluruh sektor kehidupan, baik di kalangan bisnis, pemerintahan, sistem pendidikan, dan sektor-sektor lain. Menurut kamus besar bahasa Indonesia, mutu diartikan sebagai ukuran baik buruk suatu benda; kadar; taraf atau derajat (kepandaian, kecerdasan, dan sebagainya), kualitas. ${ }^{5}$ Menurut kamus bahasa Arab, mutu diterjemahkan dalam lafadh جودي (jaudiynn). ${ }^{6}$ Dalam bahasa Inggris, disebutkan dengan quality, dan menjadi bahasa Indonesia dengan kualitas. Kata terakhir ini juga sering menjadi perbincangan banyak kalangan masyarakat tanpa mengenal kelas social dan keilmuan. Semua orang tahu tentang apa itu kualitas dan mutu, tapi tidak semuanya memahami dengan detail ketika ditanya standard an kualifikasi mutu dan kualitas. Masyarakat umum hanya bisa merasakan hasil dan efek dari sebuah upaya yang menghasilkan kerja bermutu dan berkualitas.

Al-Qur'an sebagai pedoman hidup dan kehidupan umat Islam serta umat manusia telah memperkenalkan konsep tentang mutu. Allah menyuruh kepada kita semua agar

\footnotetext{
5 Tim penyusunan Kamus Pusat Pembinaan dan Pengembangan Bahasa, Kamus Besar Bahasa Indonesia (Jakarta: Balai Pustaka, 1996), 677.

6 Ahmad Warson Munawir dan Muhammad Fairuz, Al Munawwir, Kamus Indonesia - Arab (Surabaya: Pustaka Progressif, 2007), 594
}

$$
\begin{array}{lll}
\text { Vol. } 1 \text { No. 1, A pril } 2019 & \begin{array}{l}
\text { Dr. Maskuri, M.Pd.I } \\
\text { gurnal Pengabdian Masyarakat }
\end{array}
\end{array}
$$


memperhatikan keadilan dan kebajikan. Dua hal tersebut menjadi prasyarat agar bisa menapaki jalan kehidupan yang bermutu, baik untuk dirinya maupun orang lain. Allah berfirman dalam surat An-Nahl ayat 90, yaitu:

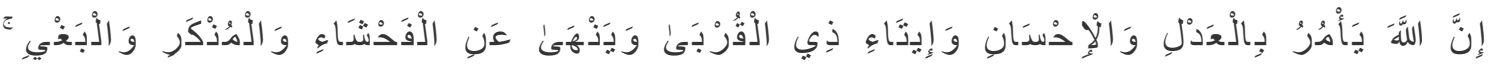

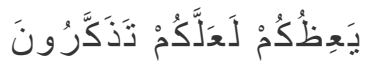

"Sesungguhnya Allah menyuruh (kamu) berlaku adil dan berbuat kebajikan, memberi kepada kaum kerabat, dan Allah melarang dari perbuatan keji, kemungkaran dan permusuhan. Dia memberi pengajaran kepadamu agar kamu dapat mengambil pelajaran."”

Dalam penjelasannya, Quraish Shibah, mengutip kitab Al-Mustadrak, disebutkan suatu riwayat yang bersumber dari Ibnu Masud, bahwa ayat di atas adalah ayat yang paling padat mengandung anjuran melakukan kebaikan dan menjauhi keburukan. Menegakkan keadilan dan melakukan perbuatan baik dibutuhkan persiapan matang dan proses serius. Setiap orang ada potensi menyeru perbuatan baik kepada orang laina. Susunan kata dan kalimat indah bisa saja diucapkan, namun apakah seruan yang indah itu mampu menginternalisasi dalam jiwa seseorang? Agar seruan kebaikan sebagai proses menuju kualitas dan mutu seseorang, maka orang yang mengajak juga harus memiliki jiwa yang baik. Nilai-nilai kebaikan hanya bisa ditanam dengan cara yang baik. ${ }^{8}$

Umat Islam dinyatakan sebagai umat yang terbaik, yaitu umat yang mampu melakukan amar ma'ruf dan nahi munkar. Indikator umat terbaik mensyaratkan kebaikan juga. Begitu pun dengan nahi munkar, umat harus berani dan memiliki strategi dakwah yang baik, sehingga tidak meninmbulkan persoalan kemunkaran baru. Umat terbaik diantara umat yang lain bukanlah sekedar slogan dan motto yang hanya dibaca dan didengungkan sebagai kesombongan diri di atas umat lainnya. Sebagai umat terbaik, umat yang terpilih, Allah berfirman dalam surat Ali Imron ayat 110, sebagai berikut:

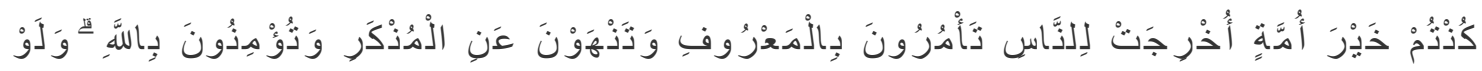

${ }^{7}$ QS. Al Nahl: 90

${ }^{8}$ M. Qurais Shihab, Tafsir Al-Misbah

Vol. 1 No. 1, April 2019 


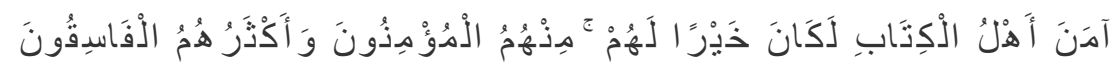

"Kamu adalah umat yang terbaik yang dilahirkan untuk manusia, menyuruh kepada yang ma'ruf, dan mencegah dari yang munkar, dan beriman kepada Allah. Sekiranya Ahli Kitab beriman, tentulah itu lebih baik bagi mereka, di antara mereka ada yang beriman, dan kebanyakan mereka adalah orang-orang yang fasik."

Membentuk dan mempertahankan umat terbaik dibutuhkan proses yang berkelanjutan. Tidak hanya menggunakan parameter teks, namun kontekstual dengan dinamika kemajuan teknologi yang terus meningkat. Lembaga pendidikan Islam mengharuskan adanya kesiapan dan kemauan untuk melakukan perubahan agar melahirkan umat terbaik. Langkah kreatif dan inovatif harus dilakan dalam mengadopsi seluruh proses perubahan agar tetap survive di tengah tantangan arus globalisasi. ${ }^{10}$ Menghasilkan lulusan pendidikan Islam yang bermutu adalah kebutuhan bukan keinginan saja. Diperlukan kesiapan mental, pemahaman dan penguasaan ilmu pengetahuan dan teknologi yang memadai, pengelolaan yang baik dan benar, serta pemenuhan sarana-prasarana yang cukup. Umat Islam, dengan lembaga pendidikannya jangan sampai mengalami romantisme sejarah masa kejayaan, masa di mana kajian Islam hanya dilakukan sekedarnya. Perlu komitmen bersama di kalangan penyelenggara dan pengelola satuan pendidikan Islam yang berorientasi mutu.

Nana Syaodih Sukmadinata, sebagaimana tulis Fathurrohman, mengidentifikasi basic yang harus dipersiapkan dalam rangka menjadikan mutu dalam sebuah proses pendidikan, yaitu 1) perlunya komitmen melakukan perubahan yang diterapkan dalam pola kepemimpinan, 2) kejelasan terhadap pemahaman sebuah kondisi real, 3) memiliki visi yang jelas untuk menatap masa depan yang penuh tantangan. Karena kunci utama menjadikan pendidikan bermutu adalah komitmen melakukan perubahan sebagai pintu

${ }^{9}$ QS. 3/Ali Imron: 110. Di Pesantren Sukorejo, kalimat Khoiru Umat menjadi visi pesantren. Pada saat pebahasan rancangan statuta Unib muncul wacana untuk dikaji ulang. Pernyataan kalimat dalam visi memang seharusnya bisa diukur, sehingga mudah dilaksanakan. Penjabaran visi selanjutnya dimasukkan dalam pernyataan misi. Kalimat khoiru umat terasa abstrak, sulit diidentifikasi secara operasional dan teknis.

${ }^{10}$ Muhammad Fathurrohman dan Sulistyorini, Implementasi Manajemen Peningkatan Mutu Pendidikan Islam (Yogyakarta: Teras, 2012), 300.

$$
\text { Vol. } 1 \text { No. 1, April } 2019
$$


masuk sebuah inovasi. ${ }^{11}$ Pondok pesantren sebagai salah satu, bahkan yang terdepan sebagai lembaga pendidikan Islam sudah banyak melakukan proses inovasi. Sebagai pendidikan tradisional, pesantren sudah mereformasi diri dengan melakukan adopsi pembelajaran modern, dan realita ini sudah banyak kita saksikan. Para aktivis Islam telah mengembangkan pendidikan pesantren dengan membentuk visi yang sangat jelas dan ideologis. Hal itu dilakukan sebagai salah satu upaya membendung arus kapitalisasi global yang sudah melanda berbagai lini institusi sosial, termasuk pendidikan yang ada di pesantren. $^{12}$

Untuk memenuhi kebutuhan akan mutu pendidikan, salah satu prasyaratnya adalah ketersediaan sumber daya yang berkualitas dan memadai. Kualitas memang sejajan dengan mutu, karena itu kata "kualitas" perlu diperjelas secara epistemologi. Menurut Iyung Pahan, sebagaimana tulis Barnawi dan M. Arifin, kualitas adalah keseluruhan gambaran dan karakteristik menyeluruh dari barang dan jasa sehingga memberikan efek memuaskan dengan dukungan kemampuan yang dimilikinya. ${ }^{13}$ Dalam konteks lain, kualitas yang memiliki padanan dengan mutu merupakan sesuatu yang berhubungan dengan baik buruk, taraf atau derajat sesuatu. Istilah kualitas lebih sering digunakan dalam dunia bisnis, rekayasa, dan manufaktur. Produk yang berupa barang atau jasa akan dikatakan berkualitas manakala konsumen sebagai pengguna barang dan jasa merasakan kepuasan. Dalam penyelenggaraan pendidikan, mutu atau kualitas akan dirasakan oleh masyarakat sebagai pengguna layanan penyelenggaraan pendidikan, asumsi atau pendapat masyarakat akan menjadi faktor dominan dalam menilai kualitas pendidikan.

Beberapa Negara sering dijasikan sebagai rujukan dalam hal pengembangan mutu pendidikan. Salah Negara yang patut kita jadikan sebagai Negara yang memiliki komtimen mutu adalah Jepang. Budaya disiplin, menghargai waktu dan kompetensi menjadi tontonan yang sekaligus menjadi tuntutan dari berbagai Negara. Di media social, melalui youtube

\footnotetext{
${ }^{11}$ Ibid, 364.

12 Nurani Soyomukti, Teori-Teori Pendidikan: dari Tradisional, (neo) Liberal, Marxis-Sosialis, hingga Postmodern (Yogyakarta: Ar Ruzzmedia, 2015), 222.

13 Barnawi dan M. Arifin, Sistem Penjaminan Mutu Pendidikan; Teori dan Praktik (Yogyakarta: Ar-Ruzzmedia, 2017), 15. 
banyak kita saksikan orang Jepang menundukkan kepala dan badannya di tengah jalan sebagai isyarat memberikan kehormatan dan ucapan terima kasih kepada orang lain. Untuk itu di Jepang dikenal dengan istilah Kaizen sebagai budaya mutu. Secara etimologi kaizen berasal dari kai yang berarti perubahan, dan žen berarti baik. Perubahan menuju kebaikan adalah komitmen bersama yang telah membudaya di Jepang. Falsafah kaizen mendorong semua orang untuk bekerja dengan cara yang baik, bergaul di tengah kehidupan social dengan baik, rumah tangga yang ideal, dan lain sebagainya, itu semua harus terus disempurnakan setiap saat. Sehingga secara berkesinambungan cara kerja yang baik selalau mengikuti dinamika perkembangan. ${ }^{14}$

Dalam konteks mutu pendidikan, sebagaimana dijelaskan di atas, umat Islam yang sedang menyelenggarakan pendidikan harus memiliki komitmen untuk mewujudkan. Stigma buruk sebagian masyarakat terhadap pendidikan yang dikelola umat Islam semakin hari semakin menghilang. Hilangnya stigma buruk karena pendidikan Islam telah dikelola dengan komitmen mutu yang tinggi, bahkan menjalar sebagai budaya kerja. Ada rasa malu dikalangan pengelola pendidikan Islam, apa pun bentuknya, manakala tidak memperhatikan mutu. Kepuasan pengguna jasa layanan pendidikan menjadi motivasi sekaliugus niat kolektif. Bukan sekedar keinginan, tetapi kebutuhan akan mutu pendidikan Islam menjadi keharusan yang tak terelakkan.

\section{Gambaran Kegiatan}

Sesuai perencanaan dan pelaksanaan kegiatan pendampingan pengabdian yang dilakukan di LPM Pondok Pesantren, dapat dijelaskan beberapa hal penting untuk menggambarkan kegiatan pendampingan ini. Hal-hal yang perlu kami sampaikan adalah:

1. Kegiatan pendampingan dilakukan secara berkelompok yang terdiri dari ketua dan anggota. Sebelum perencanaan dilakukan, tim terlebih dahulu mengidentifikasi kondisi dan informasi penting terhadap keadaan dan situasi lingkungan Pesantren Sukorejo. Identifikasi ini bertujuan untuk mengetahui problematika pengembangan pesantren yang akan dijadikan acuan dalam kebijakan mutu pesantren.

14 Muhammad Fathurrohman dan Sulistyorini, Implementasi Manajemen Peningkatan Mutu Pendidikan Islam (Yogyakarta: Teras, 2012), 49. 
2. Setelah identifikasi dilakukan dan dirumuskan, tim kemudian menyusun rencana kegiatan sesuai dengan apa yang menjadi kebutuhan Pesantren Sukorejo dalam hal peningkatan mutu. Sebelum LPM ini dibentuk, Pesantren Sukorejo sebenarnya sudah diasumsikan dan diangap oelh sebagian masyarakat sebagai pesantren yang bermutu. Namun, seiring berjalannya waktu dan perkembangan ilmu pengetahuan dan teknologi, tantangan zaman, dan pemenuhan kebutuhan peningkatan mutu yang menjadi harapan masyarakat, Pesantren Sukorejo harus membenahi diri (lembaga dan segala unit-unit kerjanya) semua perangkat yang menjadi pendorong tercapainya cita-cita. Untuk kebutuhan ini, tim pendamping bersama dengan seluruh anggota LPM merumuskan profil dan pedoman pelaksanaan kegiatan LPM. Pedomana itu antara lain menjelaskan posisi LPM bagi kebutuhan pesantren ke depan, menjelaskan visi, misi, tugas dan tanggung jawab, serta laporan progressnya. Selain penjelasan intitusi LPM, dalam rumusan dokumen profil dan pedoman LPM juga dijelaskan tentang sasaran mutu yang akan dilakukan oleh LPM.

3. Proses selanjutnya, setelah pedoman LPM disusun, pengurus LPM menyampaikan gagasan dihadapan pengasuh dan pengurus harian pesantren. Untuk kepentingan kegiatan ini, tim bukan saja memberikan pendampingan, tetapi ikut memberikan penjelasan tambahan bagi maksud dan tujuan pedoman. Randangan pedoman LPM kemudian ditanggapai dan kemudian ditetapkan oleh Pengasuh Pesantren Sukorejo.

4. Tahap kegiatan selanjutnya adalah melakukan sosialisasi pedoman LPM kepada unitunit kerja Pesantren Sukorejo. Poin penting yang harus dilakukan oleh LPM, sebagai target utama yang harus dikerjakan adalah memberikan pendampingan kepada perguruan tinggi dibawah koordinasi Bidang Pendidikan Tinggi Pesantren. Maka, dalam hal sosialisasi pedoman LPM, bidang Dikti menjadi unit organisasi pertama yang menjadi sasaran sosialisasi.

5. Selain kegiatan di atas, LPM dan tim pendamping juga ikut memberikan kontribusi pemikiran terhadap penyempurnaan penyusunan pedoman pesantren. Pedoman yang berisi pengaturan dan pelaksanaan bagi seluruh pengurus pesantren dalam menjalan tugas dan kewajibannya. 


\section{Dinamika Keilmuan}

Proses pendampingan yang telah dilaksanakan, sebagaimana gambaran kegiatan di atas, dapat menjadi wahana bagi pengembangan keilmuan. Berdasarkan kajian teori dan fakta serta data yang ditemukan oleh tim pendamping, proses ini membawa dinamika keilmuan tersendiri bagi kepentingan akademik. Pendampingan ini dimaksudkan untuk memberikan kontribusi bagi proses pengembangan Pesantren Sukorejo dalam menatap masa depan agar menjadi lembaga pesantren yang bermanfaat bagi kepentingan agama, bangs, dan Negara. Membahas pesantren dengan berbagai perspektif memang tidak akan pernah kehabisan bahan dan materi. Setiap pesantren memiliki keunikan dan karakteristik yang berbeda-beda. Namun varian pesantren dengan segala keunikannya tidak mengurangi unsur-unsur yang wajib dipenuhi. Dalam penelitiannya, Zamahsyari Dhofir menyampaikan bahwa dikatakan pesantren apabila memenuhi lima unsur, yaitu Kiai sebagai guru sekaligus pemimpin sentral, masjid atau mushola, asrama sebagai tempat istirahat sekaligus belajar (muthala'ah), santri yang menetap, dan pengajaran kitab kuning. Sejalan dengan dinamika perkembangan zaman, dan tuntutan kebutuhan akan pemenuhan kemajuan ilmu pengetahuan dan teknologi, pesantren sudah banyak melakukan inovasi.

Inovasi pesantren terhadap pemenuhan kebutuhan dilakukan karena para pemimpin pesantren menyadari, bahwa perubahan itu sunatullah. Dan dengan perubahan akan membawa kepada kemajuan. Agar perubahan yang akan membawa kemajuan tidak menggerus eksistensi pesantren sebagai sub kultur, maka semua pesantren telah membentenginya dengan disiplin ilmu keagamaan dan penanaman amaliyah keagamaan yang baik dan benar. Pesantren Sukorejo sebagai salah satu dari jumlah pesantren yang ada di Indonesia, sudah banyak melakukan apa yang disebut sebagai inovasi dan pengembangan. Sampai periode kepemimpinan (pengasuh) keempat, Pesantren Sukorejo telah membuktikan inovasinya kepada masyarakat, bangsa, dan Negara. Ada inovasi fisik dan sekaligus inovasi keilmuan. Inovasi fisik bisa dilihat dari banyaknya gedung-gedung yang telah berdiri untuk memenuhi kebutuhan kenyamanan pembelajaran dan kebutuhan santri sehari-sehari. Sementara inovasi keilmuan bisa dilihat dari berbagai penghargaan akademik dan non akademik. kegiatan bahsaul masail sudah semakin progressif dengan

\section{Vol. 1 No. 1, April 2019}


menghasilkan keputusan yang sangat kontekstual dengan dinamika kehidupan yang sedang berkembang di tengah masyarakat.

Dikatakan sebagai lembaga pendidikan maju, menurut Nur Efendi bisa dilihat dari empat karakteristik, yaitu:

1. Karakteristik dilihat dari konteks perubahan itu terjadi yang dipengarui oleh berbagai fator, seperti ekonomi, budaya, politik, dan sebagainya.

2. Karakteristik yang disebabkan oleh strategi pencapaian perubahan yang didukung oleh sumber daya memadai.

3. Karakteristik para pelaku perubahan dalam membangun inovasi, sejauh mana komtimen orang-orang sebagai actor perubahan mengimplementasikan inovasi sebagai basis perubahan.

4. Karakteristik dari berbagai problematika beragam inovasi itu sendiri, pemenuha kebutuhan biaya yang mencukupi, fasilitas yang memadai, bagaimana inovasi tidak menggoyah sistem yang sudah lama dibangun dan diterapkan.

\section{Teori yang Dihasilkan dari Pendampingan}

Kegiatan pendampingan yang kami lakukan ini tidak bisa dipisahkan dari perspektif teoritik. Karena itu, kegiatan pengabdian kepada masyarakat melalui LPM Pesantren Sukorejo menurut kami telah menghasilkan beberapa teori yang dapat diwacanakan lebih jauh. Beberapa teori itu adalah 1) teori perubahan, 2) teori kemajuan, 3) teori inovasi, dan 4) teori tentang mutu itu sendiri.

Teori perubahan dalam proses pengembangan melalui LPM ini karena mutu sebuah lembaga pendidikan tidak akan tercapai manakala sikap dan mental perubahan tidak ada dalam jiwa para penyelenggara pendidikan. Mental perubahan itu tergambar dalam surat al Mujadilah ayat 11. Bila ingin suatu keadaan mengalami perubahan, dari keadaan tertentu ke keadaan tertentu lainnya, terjadi dalam suasana yang berbeda, sebagaimana dijelaskan Piotr Sztompka. Perubahan dalam kontek lembaga memerlukan kreatifitas dan inovatif.

Semua orang menginginkan adanya kemajuan, namun bagaimana mencapai kemajuan membutuhkan kerja keras. Secara subyektif, kemajuan itu relativ, dikatakan maju oleh seseorang atau kelompok, belum tentu maju bagi orang lain. Sudut pandang kemajuan 
sangat dipengaruhi oleh sektor mana yang akan menjadi focus kemajuan. Jepang dikatakan sebagai Negara maju karena masyarakatnya disiplin sehingga dapat mendorong kemajuan dibidang teknologi otomotif. Namun bagi Negara lain, kemajuan Jepan belum didukung oleh tingkat kemajuan keberagamaan pada masing-masing warga negaranya. Buktinya masih ada fenomena bunuh diri sebagai tindakan suci. Bagi masyarakat Indonesia, tindakan bunuh diri bukanlah sesuatu yang suci, tapi perilaku menyimpang, baik secara agama maupun nilainilaia budaya.

Wujud dari proses perubahan dan kemajuan itu antara lain lahirnya inovasi atau pengembangan. Inovasi bisa dikategorikan sebagai sesuatu yang baru atau modifikasi dari proses kreatif dari orang-orang yang memiliki sikap mental perubahan sehingga berpikir dengan kemajuan. Dengan adanya perubahan, kemajuan, dan inovasi, maka akan menghasilkan suatu capai mutu. Suatu lembaga pendidikan dikatakan bermutu apabila ada opini yang berkembang di tengah masyarakat yang telah menerima hasil dari proses penyelenggaraan pendidikan. Mutu berkaitan dengan produk yang dihasil dari proses yang disertai adanya sikap mental perubahan dan berpikir maju.

\section{Diskusi Data}

Pelaksanaan kegiatan pendampingan melalui keterlibatan dalam LPM Pesantren Sukorejo menjadi bagian penting untuk mengimplementasikan salah satu fungsi tridarma perguruan tinggi. Bersama tim LPM, kami banyak memperoleh gambaran kegiatan pendampingan ini. Gambaran tersebut terungkap dalam berbagai data yang bisa dijadikan bahan kajian diskusi data. Data-data tersebut tidak akan terelaborasi secara ilmiah jika tidak dibarengi dengan suatu diskusi sebagai ciri khas lingkungan peguruan tinggi.

Menjadi penting ketika data yang kami temukan dalam pelaksanaan pengabdian masyarakat bergumul dalam ranah keilmuan. Suatu fakta yang diperoleh melalui proses pencarian data ditemukan, selanjutnya dijabarkan dalam kajian keilmuan. Tentu tidak semata-mata hanya menjabarkan data, tetapi dipadukan dengan kajian teori yang menjadi landasan pelaksanaan pengabdian kepada masyarakat. Itulah pentingnya data pendampingan didiskusikan dalam laporan ini. 
Pertama, berdasarkan gambaran dan pelaksanaan pengabdian masyarakat, tim mendapatkan gambaran keberadaan pentingnya Pesantren Sukorejo membentuk lembaga yang fokus pada pengembangan pesantren, yaitu menghasilkan lulusan atau santri yang bermutu dalam segala aspek, baik keilmuan maupun amalan nilai-nilai pesantren dan keagamaan. Untuk menghasilkan mutu pendidikan pesantren, LPM merumuskan visi dan misi sebagai acuan dalam pelaksanaan kegiatan membangun mutu pesantren. Sejalan dengan keinginan mutu sebagai hasil dalam proses penyelenggaraan pesantren, mental dan perilaku pengelola harus bermutu juga. Secara teoritik, mutu diperoleh manakala adanya mental perubahan dari pelaku pengelolaan pesantren. Unit-unit organisasi yang ada di pesantren semua diarahkan pada budaya mutu dan cita-cita bersama menjadikan pesantren sebagai lembaga yang bermutu.

Kedua, unit-unit organisasi yang ada di Pesantren Sukorejo bukan hanya murni memberikan layanan pendidikan saja. Ada beberapa unit organisasi sebagai pendukung penyelenggaraan pendidikan, antara lain; a) unit tata kelola keuangan meliputi unsur bendahara, badan pemeriksa keuangan dan kekayaan ma’had, bidang usaha (perekonomian) pesantren. b) bidang pekerjaan umum yang mengelola kerja-kerja layanan pesantren bagi pemenuhan sarana prasarana, membangun gedung; asrama, kantor, sekolah, dll. c) bidang kepesantren yang mengelola urusan pelaksanaan pengajian, ubudiyah, bahsul masail, dan d) bidang keamanan dan ketertiban pesantren yang mengelola urusan ketertiban dan keamanan lingkungan dan pembentukan disiplin santri agar tidak melanggar ketentuan tata tertib pesantren.

Unit-unit organisasi "kecil" pesantren tersebut secara fungsional dan operasional melaksanakan kebijakan kiai/pengasuh pesantren untuk menopang tercapainya proses penyelenggaraan pesantren agar terbentuk pesantren yang memiliki nilai mutu. Karena itulah, para pengelola pada unit-unit organisasi menjalankan tugas dan fungsinya berpedoman pada regulasi yang dibuat oleh pengasuh. Mereka semua diarahkan untuk berpikir maju dan memegang prinsip amanah dan kejuruan serta loyalitas pengabdian yang tinggi.

\section{Vol. 1 No. 1, April 2019}


Ketiga, perangkat organisasi dalam bentuk tata kelola peraturan pesantren, seperti dokumen pedoman pesantren yang berisi tentang pengaturan dasar (AD/ART), pembagian tugas dan tanggung jawab pengurus, sistem pemberian barokah (honor/gaji), mekanisme pengangkatan dan pemberhentian pengurus, tata kelola keuangan pesantren, dan tata kelola proses pengajuan rekomendasi (yang sebenarnya adalah persetujuan kiai sebagai pemegang otoritas tertinggi dalam penyelenggaraan dan pengelolaan pesantren). Perangkat atau instrumen tersebut oleh LPM dikaji ulang untuk disempurnakan dan disesuaikan dengan perkembangan zaman serta tuntutan kebutuhan pesantren/masyarakat. Karena mutu dan kemajuan sangat berkaitan dengan persepsi publik/masyarakat.

\section{Follow Up}

Pendampingan yang dilakukan di LPM Pesantren Sukorejo, sebagaimana deskripsi kegiatan di atas, tentu harus berkelanjutan, sehaingga apa yang sudah dilakukan akan menjadi pertimbangan bagi kelangsungan kegiatan yang akan datang. Kelanjutan atau follow up pengabdian akan terus berlangsung, karena LPM bukan lembaga ad hock, tetapi permanen yang berfungsi memberikan masukan dan pertimbangan kepada pengasuh untuk pengembangan penyelenggaraan pesantren. Beberapa kegiatan atau rencana kegiatan yang akan ditindaklanjuti adalah :

1. Bagi pendamping yang sekaligus pengurus LPM akan menyusun standar mutu bagi penyelenggaraan pengembangan mutu pesantren. ini menjadi prioritas karena dalam profil LPM dan kepengurusannya, divisi standar mutu belum menyusun rancangan pedoman atau standar mutu bagi unit-unit organisasi yang di Pesantren Sukorejo.

2. Dalam hal tata kelola keuangan pesantren, LPM sebagaimana sasaran kebijakan mutu, akan melakukan pendampingan pembentukan pedoman tata kelola keuangan Pesantren. Landasan norma yang digunakan LPM dalam penyusunan pedoman tata kelola keuangan Pesantren Sukorejo adalah AD/ART, pedoman kerja pengurus, pembagian tugas dan tanggung jawab, dan aturan pelaksana lainnya yang berkaitan dengan pengelolaan keuangan. 
3. Untuk pembahasan STATUTA UNIB, selanjutnya akan dipresentasikan dalam forum pengasuh pesantren dan Kementerian Riset, Teknologi, Pendidikan Tinggi melalui LL DIKTI.

4. Penyusunan Rencana Strategis (Renstra) Pesantren Sukorejo juga menjadi bagian yang sangat penting dan mendesak untuk ditindaklanjuti. Dalam hal ini, pendamping telah ditunjuk sebagai ketua penyusunan Renstra oleh Pengasuh Pesantren Sukorejo bersama tum kecil lainnya.

Dalam kontek kelangsungan pelaksanaan program dan kegiatan LPM, pendamping akan terus melakukan kerja-kerja pengabdian bagi pengembangan mutu penyelenggaraan pesantren. Bukan hanya tanggung jawab akademik saja, lebih dari itu adalah tanggung jawab individu sebagai orang yang diberi amanat untuk melaksanakan tugas dan kewajiban.

\section{Simpulan}

Berdasarkan deskripsi pendampingan dalam pengabdian kepada masyarakat yang dilakukan di LPM Pesantren Sukorejo, sebagaimana yang sudah dijelaskan di atas, maka dapat disimpulkan sebagai berikut:

1. Pesantren Sukorejo dengan mendirikan LPM telah menunjukkan betapa penting dan seriusnya menghadapi berbagai tantangan ke depan. Untuk melengkapi beberapa perangkat organisasi yang sudah ada, Pesantren Sukorejo memberikan harapan kepada LPM agar menjalankan fungsinya sebagai lembaga yang mendorong seluruh unit-unit organisasi di pesantren untuk meningkatkan mutu penyelenggaraan pesantren.

2. Sebagai lembaga baru, LPM telah menyusun profil yang berisi tentang visi, misi, dan sasaran mutu serta berbagai perangkat organisasi yang berkaitan dengan kesepahaman mutu di kalangan pesantren.

3. Kesepahaman mutu tersebut dimulai dari keterlibatan LPM dalam proses pembahasan beberapa dokumen penting pesantren yang berisikan pedoman bagi penyelenggaraan pesantren. Dokumen tersebut adalah AD/ART, tugas dan tanggung jawab pengurus, tata kelola pemberian barokah dan tunjangan bagi pengurus, mekanisme pengangkatan, penetapan, dan pemberhentian pengurus, pedoman tata kelola keuangan. 
4. Langkah awal untuk mengkonsolidasi, LPM melakukan sosialisasi keberadaan lembaganya kepada unit-unit atau pengurus pesantren yang terbagai dalam bidangbidang. Mengawali langkah ini, LPM melakukan sosialisasi dibidang pendidikan tinggi yang ada di pesantren. Hal ini sesuai dengan latar belakang pembentukan LPM yang menyertai "berdirinya kembali" Universitas Ibrahimy agar memperhatikan pendampingan terhadap keberadaan perguruan tinggi. Salah satu wujud implementasi pendampingan tersebut adalah keterlibatan dalam penyusunan statuta UNIB.

\section{Saran}

Memperhatikan simpulan sebagaimana dijelaskan di atas, ada beberapa saran sebagai langkah perbaikan ke depan dalam penyelenggaraan mutu pesantren, yaitu:

1. Hendaknya LPM menunjukkan keberadaan mutu dirinya sebagai lembaga yang berfungsi mengawal dan mengkoordinir mutu penyelenggaraan pesantren. Perangkat mutu LPM harus dikonsolidasikan secara matang dan terencana secara baik dan benar.

2. Hal-hal yang berkaitan dengan perangkat mutu bagi pelaksanaan kebijakan mutu penyelenggaraan pesantren disusun secara rapi agar mudah dipahami dan dilaksanakan oleh unit-unit organisasi yang ada di pesantren.

3. Tanggung jawab LPM begitu besar bagi keberlangsungan penjaminan mutu terhadap proses penyelenggaraan pesantren, baik urusan akademik maupun non akademik. Untuk memenuhi tanggung jawab tersebut, LPM hendaknya membudayakan mutu internalnya dalam menjalankan tugas besar tersebut. Perangkat LPM, baik suprastruktur maupun infrastrukturnya dilengkapi agar mudah menjalankan misi besar dalam persoalan mutu pesantren.

\section{Daftar Pustaka}

Arifin M, dan Barnawi, Sistem Penjaminan Mutu Pendidikan; Teori dan Praktik (Yogyakarta: ArRuzzmedia, 2017), 15.

Efendi, Nur, Manajemen Perubahan di Pondok Pesantren: Konstruksi Teoritik dan Praktik Pengelolaan Perubahan sebagai Upaya Pewarisan Tradisi dan Menatap Tantangan Masa Depan (Yogyakarta: Terass, 2014),

Fathurrohman, Muhammad dan Sulistyorini, Implementasi Manajemen Peningkatan Mutu Pendidikan 
Islam (Yogyakarta: Teras, 2012),

Nata, Abuddin, Kapita Selekta Pendidikan Islam: Isu-isu Kontemporer tentang Pendidikan Islam (Jakarta: Rajagrafindo Persada, 2016),

Shihab, M. Qurais, Tafsir Al-Misbah

Nurani Soyomukti, Teori-Teori Pendidikan: dari Tradisional, (neo) Liberal, Marxis-Sosialis, hingga Postmodern (Yogyakarta: Ar Ruzzmedia, 2015), 222.

Sztompka, Piotr, Sosiologi Perubahan Sosial (Jakarta: Prenada, 2011),

Tim penyusunan Kamus Pusat Pembinaan dan Pengembangan Bahasa, Kamus Besar Bahasa Indonesia (Jakarta: Balai Pustaka, 1996)

Warson Munawir, Ahmad, dan Fairuz, Muhammad, Al Munawwir, Kamus Indonesia - Arab (Surabaya: Pustaka Progressif, 2007)

Pedoman Pesantren Salafiyah Syafi'iyah Sukorejo

Profil LPM Pesantren Sukorejo 